\title{
The Effect of Plyometrics Exercise to Increase the Ability of Rebound
}

\author{
Dio Bagus O. Z*, Umar, Hendri Irawadi \\ Faculty of Sport Science \\ Universitas Negeri Padang \\ Padang, Indonesia \\ oddyzonata94@gmail.com
}

\begin{abstract}
The problem expressed in this research is still low explosive power of his leg muscle, and the effect of lower leg muscle explosive power is impacting the ability of the athlete to rebound the basketball club. The purpose of this study was to determine whether there is any effect on the ability plyometrics exercises rebound IKABAS club basketball athletes. This type of research is a kind of quasi-experimental research, which is forecast to information obtained by actual experiment in a state that does not allow to control and manipulate all relevant variables. Moreover, the population in this study were athletes from basketball club IKABAS, and the population sampled in this study, which numbered 20 people. In the sampling, the researchers used purposive sampling techniques that determine the sample with specific considerations that are thought to provide the data to the fullest. Based on the research that has been done, there is the influence of plyometrics exercises to increase the ability of Rebound that of the average gained 119.56 at 122.45 pre-tests be obtained at post-test $(t=4.59>t$ table $=1.729)$.
\end{abstract}

\section{Keyword-Plyometrics, Explosive muscle Legs, basketball}

\section{INTRODUCTION}

The development of the sport is currently experiencing a very rapid office. Sports are entering into life aspects such as industry, economy, and education. Indonesia is the liquid of one of the countries that are giat-giatnya implementing development in all areas. One of those areas is the construction of sports.

One of the steps made by Indonesian nation is by the birth of Law No. 3 year 2005 [1] about national sports System. The Government's objective in the field of sport is in Chapter 2 of article 4, which reads:

National sports aims to maintain and improve health and fitness, achievement, quality of human beings, instilling moral values and noble morality, sportsmanship, Discipline, strengthening and cultivating unity and unity of the nation, strengthening national resilience, and enhancing the dignity, dignity and honor of the nation.

Based on the quotations above, it can be argued that one of the areas of development that Indonesia wants to achieve is the emergence of national achievements in various sports branches. Achieving the goal of national sports is expected to grow the healthy generation of physical and spiritual, fit, quality, moral and noble, sportsmanship, discipline, which will later positively impact the national development Dibidang-bidang other. For this to be achieved, it takes totality and good cooperation between the Government, society and sports.
The sports branches are gaining attention and regional level coaching to the national level of the many sports achievements which are developed one of which is a basketball sport. Basketball games are one of the many sports that are favored by the people of the city to the villagers, from children, teenagers and parents to both men and women.

According to [2] "Gameplay in the beginning was a simple game involving many people to move physically. Nowadays, soccer games are very popular with teenagers in almost all corners of the world and often seize the attention of society in general [2].

To reach and achieve high achievement in a branch, it is necessary to do the directional cooperation and pay attention to all aspects that contribute to the achievement. The sport activities carried out must be conducted programmatically, directed and sustained, and the application of self-discipline in conducting and participating in a sports branch.

There are four factors that need to be trained to achieve peak achievement, namely physical condition, technique, tactics, and mental, the four factors are related to each other. According to [3] said that: "Physical conditions are a requirement to achieve achievement even as a necessity to be fulfilled. Therefore, each exercise program, done is to develop a component of physical condition related both in general and specifics [3]".

Physical condition exercises are basic exercises that need to be precedence, so as to support training techniques, tactics and mental. Physical condition exercises need to be planned systematically, programmatic, and directed in accordance with the principles of exercise. The goal of physical condition exercise is to improve the functional quality of body organs according to the needs and demands to achieve optimal achievement in a particular sport. With good physical condition, a basketball athlete will be easy to do some techniques that can support the implementation of a tactic and strategy that makes an athlete can also easily reach a performance.

Based on the above quotation, it can be suggested that the physical condition is an important requirement in achieving the achievement, and is one of the factors to be able to improve and solidify the technical quality in achieving a branch's peak achievement Sport-like basketball. To be able to excel in basketball, they must have a good physical condition to support their technical skills. However, the techniques that a player has without being balanced with good physical ability will be difficult to 
achieve high performance. It can spur the builders and coaches to improve the playability of the players in order to become a professional player. An element of much needed physical condition and a large effect on the performance of the basketball sport is the explosive power of the leg muscles. According to Harre in the [4] "Explosive power is one's ability to overcome prisoners with a high speed of contraction [4]

Well, the ability of a person's leg muscle's explosive power can be seen at high jumps and in a basketball game the athlete's explosive power can be seen during the rebound technique. The muscular power of the limbs can be influenced by several factors. "explosive power is determined by several factors namely the type of muscle fibers, muscle length, muscle strength, muscle temperature, fatigue, and muscle reaction to nerve stimulation" [5].

Based on the above quotation can be concluded that the explosive power of leg muscles is an element of physical condition that is influenced by several factors and plays an important role in basketball games so that they can jump high especially in doing Rebound. Limm muscle is also beneficial when doing other techniques in a basketball game. For example, when you jump shoot, lay up shoot and slam dunk.

In addition to coaching physical conditions, mastery techniques should also be trained. Engineering is a way of doing or implementing something in achieving specific objectives effectively and efficiently. Thus the technique in the basketball game can be interpreted, as a way of playing the ball effectively and efficiently in accordance with the prevailing game rules. In basketball games there are several kinds of basic techniques, among others, (1) Passing, (2) Shooting, (3) Dribble, (4) Pivot and (5) Rebound. One of the techniques that is dominant.

In order to perform the perfect rebound technique required high radiation, a player must have a strong limm muscle power to make the stepping height progressively higher and the rebound ability better so as to win the duel in the air. Hence the explosive power of leg muscles in the basketball sports branch is very important owned and upgraded by every athlete in a basketball game to do the Rebound.

Basketball Club IKABAS is one of the clubs that performs the construction of basketball games both techniques and tactics. This construction is expected to be able to achieve qualified athletes, in the account of each championship followed by the aim of achieving achievements in the match at the regional level even the national level. The frequency of exercise is done every Tuesday, Thursday, Saturday, and Sunday. The average of each athlete's workout has a workout frequency of 1 to 2 hours, with the training time starting at 15.30-18.00. The purpose of this basketball exercise is to be able to achieve achievements in the match at the local level even the national level. Based on the research observation and interview with the trainer at the time of practice training in the basketball club IKABAS, when conducting exercises as well as during the championships, there are still many athletes who have shortcomings when performing techniques Rebound. This can be seen when the player performs a duel in the air rarely once the athlete can master the ball. It makes them difficult to win the game.

According to information from the basketball coach IKABAS, the ability to rebound is still less caused by the low-explosive power of the athlete's muscles so as to win the duel in the air is difficult. Thus it can be said that the explosive power of the muscles of a basketball athlete's limbs IKABAS is still low so that the stepping is done at the time of Rebound is still lacking.

Low ability to rebound due to several factors, among others, the explosive power of the limbs, the plyometrics exercise form provided by the trainer is not optimal. In addition, there are many more things that affect the rebound ability such as lack of facilities and infrastructure, nutrition, trainer ability in selecting exercise models, and training programs given by coaches.

In the club IKABAS the visible factor is the lack of training models aimed at improving the explosive power of the limbs. Coaches more often provide practice techniques, tactics and strategies. The physical exercises provided are not focused on the explosive power of the limbs but only focuses on the exercise of other physical conditions. From several factors causing low ability to rebound basketball athletes IKABAS, researchers only choose exercise, because with plyometrics exercises will gain a lot of usability in improving the ability of Rebound and explosive power of the limbs So that it will be able to support an athlete to achieve a resounding success in rebounds in order to achieve the expected victory.

Based on the above problems then authors are interested to conduct research on basketball athletes IKABAS with Plyometrics exercises as a free variable and increased ability to rebound as a bound variable.

\section{RESEARCH METHODS}

In accordance with the purpose of this research is to reveal the effect of the plyometrics exercises on increased rebound ability, this type of research includes the SEMU Experiment (Quasi experiment). The free variables in this study are the plyometrics exercises. While the other variable is increased rebound ability.

The design in this study is using one group pre-test and post-test:

$$
\begin{array}{lll}
0_{1} & \mathrm{X} & 0_{2}
\end{array}
$$

Information :

$0_{1}$ : Pre Test (before treatment is given)

$\mathrm{X}$ : Treatment

$\mathrm{O}_{2}$ : Post Test (After given treatment)

"Population is the whole of the subject of research" [6]. The population in this study was the entire basketball athlete IKABAS consisting of 20 sons and 15 daughters. For more clarity on population spreads can be seen in the following table.

According to [6] "samples were partially or representatives of the population being studied". Based on the above population, sampling of the research was conducted with the technique of "purposive sampling". "Purposive Sampling is determining the sample with certain 
considerations that are deemed able to provide maximum data" [6].

Data collection techniques for measuring the explosive power of leg muscles are performed with a vertical jump test. The instrument or data collection tool in the study was Vertica Jump.

According to the [6] "Measurements of the muscular power of the limbs can use the standing broad jump to measure the muscular power of the limbs towards the front and vertical jump to measure the explosive power of the muscles of the limbs towards the upper. And in this study used a vertical jump as an explosive power gauge of leg muscles "[6].

To find out the extent of the effect of the Plyometrics exercises on the increased explosive power of the athlete's leg muscle athletes IKABAS. Then the obtained data is analyzed by the statistical formula using the analysis technique "T-Test or T test".

$$
\mathrm{t}=\frac{\left|\bar{X}_{1}-\bar{X}_{2}\right|}{\sqrt{\frac{\sum D^{2}-\frac{\left(\sum D\right)^{2}}{n}}{n(n-1)}}}
$$

Keterangan :

$\mathrm{t}=$ Price of $\mathrm{T}$ Test is sought

$\bar{X}_{1} \quad=$ Average (mean) explosive muscle leg Pre-test

$\bar{X}_{2}=$ Average (mean) the explosive power of the

postest Limm muscles

D = Average difference in pre-tests data with post-

test

$\mathrm{D}^{2} \quad=$ Quadratic difference

$\sum \mathrm{D}^{2}=$ Number of quadratic differences

$\mathrm{n} \quad=$ Number of samples

\section{RESEARCH RESULTS}

\section{A. Data Description}

\section{The Effect of Plyometrics exercises on increased} Rebound ability.

From the results of a pre-test group exercise the plyometrics obtained the lowest value of the 98.2 highest value of 134.5 its average is 119.56 and its standard deviation is 10.58 . From the post test results after being given the treatment for 16 times the meeting obtained the lowest value of 104 the highest value of 138.3 its average is 122.45 and the standard deviation is 10.26 .
Tabel 1. Frequency distribution of Data Pre Test and Post Test Vertical Jump

\begin{tabular}{|c|c|c|c|c|c|}
\hline \multirow{3}{*}{$\begin{array}{l}\text { Interval } \\
\text { class }\end{array}$} & \multirow{2}{*}{\multicolumn{2}{|c|}{$\begin{array}{c}\text { Frequency } \\
\text { Pre Test }\end{array}$}} & \multirow{2}{*}{\multicolumn{2}{|c|}{$\begin{array}{c}\text { Frequency } \\
\text { Post Test } \\
\end{array}$}} & \multirow{3}{*}{ Criteria } \\
\hline & & & & & \\
\hline & $\mathbf{F a}$ & $\operatorname{Fr}(\%)$ & $\mathbf{F a}$ & $\operatorname{Fr}(\%)$ & \\
\hline $301>$ & 0 & $0 \%$ & 0 & $0 \%$ & Excellent \\
\hline $240-300$ & 0 & $0 \%$ & 0 & $0 \%$ & Good \\
\hline $115-239$ & 13 & $65 \%$ & 14 & $70 \%$ & Enough \\
\hline 54-114 & 7 & $35 \%$ & 6 & $30 \%$ & Less \\
\hline $0-53$ & 0 & $0 \%$ & 0 & $0 \%$ & The lack of \\
\hline Amount & 20 & $100 \%$ & 8 & $100 \%$ & \\
\hline
\end{tabular}

Description:
$\mathrm{Fa} \quad$ : Absolute frequency
Fr : Relative frequency in percent

Guided to the table, it can be seen that the results of data analysis pre test vertical jump with the category either no, category 0 , category enough as much as 13 people $(65 \%)$, the category of less than 7 people (35\%), and a category of less than once as much as 0 people, the results of the post test vertical jump with a good category of 0 , the category of good as 0 people, the category is quite 14 people $(70 \%)$, the category is less than 6 people (30\%), and the category of lack of athletes who acquired.

Based on the distribution, there is clearly increased rebound ability.

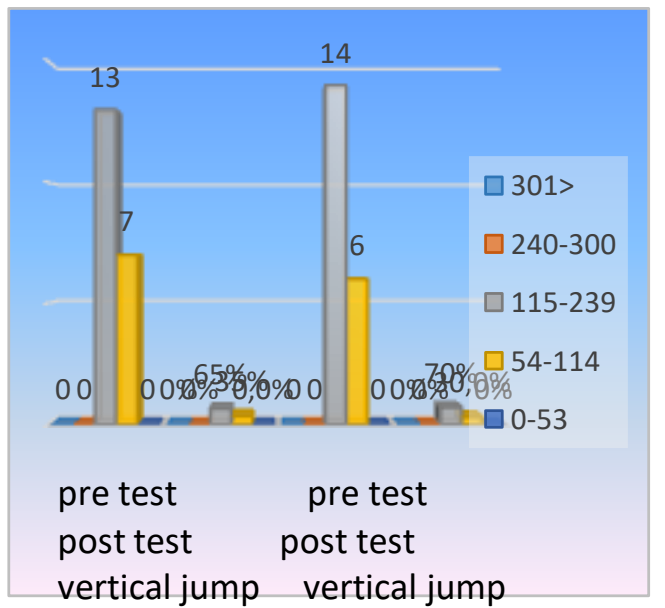

Graphique De la distribution de fréquences histogrammes Avant le test et après le test a augmenté la capacité de rebond

\section{B. Normality test}

The hypothesis of this study was tested using $\mathrm{t}-\mathrm{The}$ research hypothesis was tested by conducting a T-Test analysis, before conducting a T-Test analysis, first conducted a test of normality to determine whether data came from a normal distribution or not using test statistics. Lilliefors with a significant level $\Lambda=0.05$. 
Table 2. Test result summary normality increased rebound ability

\begin{tabular}{|c|c|c|c|}
\hline Group & L Count & L table & Description \\
\hline Pre test & 0,1106 & \multirow{2}{*}{0,19} & Normal \\
\hline Pre test & 0,1212 & & \\
\hline
\end{tabular}

Based on the test results of the normality of research above, we get the price of lcount obtained smaller than Ltabel. It can thus be concluded that all the data groups in this study were taken from the normal distribution population, so that they could be used for hypothesis testing.

C. Hypothesis testing.

Once analysis requirements are tested and it turns out all variable data meets the requirements for testing hypotheses. The statistical test used is a T-test with a significant level of 0.05 .

The proposed hypothesis is that the Plyometrics exercises affect the increased ability of the football athlete rebound IKABAS. Based on the results of the hypothesis testing, there was an influence on the form of the plyometrics exercise against the increased ability of basketball athlete rebound IKABAS with the results of $\mathrm{L}_{\text {count }}$ (4.59) > Ltabel (1.729).

Table 3. Hypogerm of hypothesis testing results

\begin{tabular}{|c|c|c|c|}
\hline Group & $\mathbf{t}_{\text {Count }}$ & $\mathbf{t}_{\text {table }}$ & Description \\
\cline { 1 - 1 } Pre test & \multirow{2}{*}{4.59} & 1.729 & significant \\
\cline { 1 - 1 } Pre test & & & . \\
\hline
\end{tabular}

Based on the table it can be said that there are influences of plyometrics exercises on the increase of rebound ability $($ Tcount $=4.59>$ Ttable $=1.729)$, thus the proposed hypothesis is accepted.

\section{DISCUSSION}

There is a Plyometrics exercise influence on the increased Rebound ability

The discussion of research results is intended as an overview to make it easier to draw research conclusions. Rebound technique is one of the important techniques in basketball games. This is the core thing to achieve a maximum result, and it is also based on regular exercise according to the established training program. Thus, in the results of the first hypothesis test is explained that there is a significant influence of Plyometrics exercises to increase rebound ability, because it is one form of exercise or exercise method that can improve the ability Rebound in this basketball game. Before treatment of samples were first performed pre-Test. Based on the results of the test, the power of club IKABAS was acquired on average at pre-test of 119.56. However, after a 16-time treatment with the form of the plyometrics exercise, an average increase of 122.45 was made in basketball athletes of the IKABAS club. With the results of this research can be concluded that the plyometrics exercises affect the rebound ability of basketball athletes club IKABAS. This is reinforced after TTest, where the results of Thitung amounted to 4.59, which is larger than the amount of $\alpha=0.05$ of 1.729 .

By conducting plyometrics exercises continuously in accordance with a well-designed and tailored training program it can increase the explosive power of the limbs and that affects the increased rebound ability. Based on the results of the research, we can conclude that there are influences of the plyometrics exercises to increase the ability to rebound basketball athletes club IKABAS.

\section{CONCLUSIONS}

Based on the analysis and discussion that has been done in the previous chapter, this chapter will be given the following conclusions and suggestions:

exercise plyometrics can improve the ability meaningfully, can be proved with thitung data $=4.59>$ Ttabel $=1.729$. With an average of 119.56 (pre-Test) 122.45 (post test) increased by 2.89

\section{REFERENCES}

[1] Undang-undang RI No 03. 2005. "Sistem Keolahragaan Nasional”. Yogyakarta : Pustaka Yudisti. 2005.pp.10-22.

[2] F, Adnan. "Bola Basket Dasar". Padang UNP. 1999.pp.33-45

[3] M, Madri. "The Basic Learning Basketball Technique".Padang: Sukabina Press. 2012. Pp.45-66.

[4] Arsil. "Pembinaan Kondisi Fisik". Padang: Fakultas Ilmu Keolahragaan UNP. 1999.pp.12-33.

[5] I, Hendri. "Kondisi Fisik Dan Pengukurannya". Padang: UNP PRESS. 2014.pp.55-76.

[6] A, Suharmi. "Prosedur Penelitian". Jakarta: Rineka Cipta. 2008.pp.21-32. 